\title{
HUKUM PERMODALAN DALAM ISLAM
}

\author{
Nurul Annisa \\ Perbankan Syariah Fakultas Ekonomi dan Bisnis Islam \\ Universitas Islam Negeri Alauddin Makassar \\ Email: nurulannisa036@gmail.com
}

\begin{abstract}
Capital in Islam can be obtained from two possibilities, the first is debt and the second is investment using a syirkah contract, if you want to attract capital by way of debt, you must understand the laws of dayn dan qardh. Debt is an obligation for someone to pay if the debt maturity has been up, even the debt shall be the duty of someone since he was alive until he dies. Therefore if a muslim wants to increase capital by way debt, it must be in accordance with the prescribed sharia so that in the future there will be no unwanted problems and avoid usury.
\end{abstract}

Keywords: Capital, debt, Islam Economic

\section{A. Pendahuluan}

Modal adalah dana yang diserahkan oleh para pemilik. Pada akhir tahun buku, setelah dihitung keuntungannya yang didapat pada tahun tersebut, pemilik modal akan memperoleh bagian dari hasil usaha yang biasa dikenal dengan deviden. Dana modal dapat digunakan untuk pembelian gedung, tanah, perlengkapan dan sebagainya yang secara langsung tidak menghasilkan. Selain itu juga modal dapat digunakan untuk hal-hal yang produktif, yaitu disalurkan menjadi pembiayaan yang berasal dari modal, hasilnya tentu saja bagi pemilik modal, tidak dibagikan kepada pemilik dana lainnya (Antonio, 2004: 146).

Secara tradisional, modal didefenisikan sebagai sesuatu yang mewakili kepentingan pemilik dalam suatu perusahaan. Berdasarkan nilai buku, modal didefenisikan sebagai kekayaan bersih (net worth) yaitu selisih antara nilai buku dari aktiva dikurangi dengan nilai buku dari kewajiban (liabilities) (Arifin, 2006:135) 
Permodalan dalam islam dapat diperoleh dari dua kemungkinan, yang pertama yaitu berhutang (dayn dan qardh) dan yang kedua investasi menggunakan akad syirkah, jika permodalan dari harta pribadi maka tidak perlu pembahasan lanjut. Jika ingin menarik modal dari pihak lain maka harus memahami hukum-hukum dayn, qardh dan syirkah terlebih dahulu. Dalam tulisan ini akan lebih fokus pada hukum utang-piutang.

\section{B. Pembahasan}

\section{Penambahan Permodalan Dengan Utang}

Dalam bahasa Arab, utang merupakan sesuatu yang berada dalam tanggungjawab orang lain. Dayn disebut juga dengan صو ثة ذلا ف (sesuatu yang harus dilunasi atau diselesaikan. Menurut Hanafiyah, dayn termasuk kepada al-milk. Utang dapat dikatagorikan pada al-Māl al-Hukmi: "sesuatu yang dimiliki oleh pemberi utang, sementara harta itu berada pada orang yang berutang." Sehingga utang negara adalah milik rakyat dan dipergunakan untuk keperluan rakyat. Selain itu, utang secara bahasa utang juga dapat bermakna memberikan pinjaman. Al Dayn mensyaratkan jangka waktu tertentu dalam pengembalian utang, hal ini yang membedakan al-Qardh yang tidak mensyaratkan jangka waktu tertentu dalam pengembalian utangnya, dayn lebih umum dari al-qardh (Nurul Huda, 2012: 239).

Menurut Abu Al-Kasim kata dayn berarti memberi utang atau berhutang. dan kata qardh memiliki arti apa yang dibayarkan kepada orang lain dari harta dengan syarat mengembalikannya sebagai gantinya (Abu Al-kasim, 233). Adapun menurut al-Mu"jam alWasid kata dayn adalah adalah utang yang bertempo sedangkan qardh utang yang tidak bertempo (Al-muejam al-wasid, 2004: 307). Qardh kamu memberikan harta kepada orang lain dengan mengharapkan pengembalian darinya. Qardhul Hasan berarti memberikan pinjaman tanpa keuntungan atau bunga, ini bisa digunakan untuk yang abstrak baik yang menyangkut kebaikan atau keburukan (Al-Mu'jam Al-Wasid, 2004: 307). Jadi baik kata dayn maupun kata qardh adalah kata yang bermakna utang yang memiliki tempo dan tidak bertempo.

Hutang secara terminologi adalah memberikan harta kepada orang yang akan memanfaatkannya dan mengembalikan ganti rugi dikemudian hari (Abdullah bin Muhammad ath-Thayyar, 2009: 152). Sedangkan menurut Kompilasi Hukum Ekonomi Syariah, hutang adalah penyediaan dana atau tagihan antar lembaga keuangan syariah dengan 
pihak peminjam untuk melakukan pembayaran secara tunai atau cicilan dalam dalam jangka waktu tertentu. Definisi yang dikemukakan dalam Kompilasi Hukum Ekonomi Syariah bersifat apikatif dalam akad pinjam-meminjam antara nasabah dan Lembaga Keuangan Syariah. Adapun sebab dari tetpanya utang ada 3, yaitu:

a. Utang karena pertukaran (mu'awadhah). Ternyata utang dagang atau kredit itu boleh, bisa karena jual beli, dari akad ijarah.

b. Utang karena merusak barang orang lain (Itlaf). Misalnya merusak mobil, motor, rumah orang lain itu ada tanggungan untuk memperbaiki.

c. Utang karena pinjaman (qardh). Contohnya pinjam uang kepada orang lain.

\section{Hukum Utang Piutang}

Hukum Utang piutang pada asalnya diperbolehkan dalam syariat Islam. Bahkan orang yang memberikan utang atau pinjaman kepada orang lain yang sangat membutuhkan adalah hal yang disukai dan dianjurkan, karena di dalamnya terdapat pahala yang besar. Adapun dalil-dalil yang menunjukkan disyariatkannya utang piutang ialah sebagaimana berikut ini:

“ Hai orang-orang yang beriman, apabila kamu bermu'amalah tidak secara tunai untuk waktu yang ditentukan, hendaklah kamu menuliskannya, dan hendaklah seorang penulis di antara kamu menuliskannya dengan benar, dan janganlah penulis enggan menuliskannya sebagaimana Allah mengajarkannya, maka hendaklah ia menulis, dan hendaklah orang yang berhutang itu mengimlakkan apa yang akan ditulis itu, dan hendaklah ia bertakwa kepada Allah Tuhannya, dan janganlah ia mengurangi sedikitpun daripada hutangnya. Jika yang berhutang itu orang yang lemah akalnya atau lemah keadaannya atau dia sendiri tidak mampu mengimlakkan, maka hendaklah walinya mengimlakkan dengan jujur. dan persaksikanlah dengan dua orang saksi dari orang-orang lelaki di antaramu. jika tak ada dua oang lelaki, maka boleh seorang lelaki dan dua orang perempuan dari saksi -saksi yang kamu ridhai, supaya jika seorang lupa maka yang seorang mengingatkannya. janganlah saksi-saksi itu enggan memberi keterangan apabila mereka dipanggil; dan janganlah kати јети тепulis hutang itu, baik kecil maupun besar sampai batas waktu membayarnya. Yang demikian itu, lebih adil di sisi Allah dan lebih menguatkan persaksian dan lebih dekat kepada tidak menimbulkan keraguanmu. Tulislah 
ти'aтalahти itu, kecuali jika mu'amalah itu perdagangan tunai yang kamu jalankan diantara kamu, maka tidak ada dosa bagi kamu, jika kamu tidak menulisnya. dan persaksikanlah apabila kaти berjual beli; dan janganlah penulis dan saksi saling sulit menyulitkan. jika kamu lakukan yang demikian, maka sesungguhnya hal itu adalah suatu kefasikan pada dirimu, dan bertakwalah kepada Allah; Allah mengajarmu; dan Allah Maha mengetahui segala sesuatu."

Ayat ini menjelaskan, bahwa dalam bertransaksi yang dilaksanakan idealnya harus tercatat agar ada pegangan diantara pihak yang bertransaksi sebagai bukti etintik. Pada era sekarang ini, sering terjadi permasalahan dikarenakan tidak ada bukti tertulis, sehingga pihak yang bertransaksi saling menyangkal, hal ini memungkinkan karena memiliki nilai yang menguntungkan pada salah satu pihak sehingga ada pihak yang dirugikan.

Berarti bermu'amalah secara tidak tunai itu boleh, baik dayn Mu'awwadah, dayn itlaf, maupun dayn qaardh itu oleh semua karena termasuk dayn. Utang-piutang (dayn) hukumnya adalah mubah atau jaiz, walaupun ulama membedakan antara yang memberi utang dan yang berutang. Kalau yang memberi utang disebut al-muqridh hukumnya sunnah atau mandub dianjurkan tapi yang berutang disebut al-muqtaridh hukumnya mubah walaupun sebagian ulama mengatakan sunnah.

Adapun hadis Nabi untuk yang memberi utang :

Dari Ibnu Mas'ud RA, bahwa Rasulullah SAW bersabda, "Tidakkah seorang muslim memberi pinjaman kepada muslim yang lain sebanyak dua kali, kecuali hal itu seperti sedekah satu kali.” (HR Ibnu Majah). Sedangkan untuk yang berutang:

Dari Muhammad bin Ali dia berkata 'Aisyah RA telah berutang piutang, lalu ada yang bertanya kepadanya, "Mengapa Anda berutang? 'Aisyah menjawab, "Aku pernah mendengar Rasulullah SAW bersabda, "Tidakkah seoranhg hamba berniat untuk melunasi utangnya, kecuali dia berhak mendapat pertolongan dari Allah Azza wa Jalla. Maka aku mencari pertolongan Allah itu” (HR Ahmad\& Thabrani). 
Ulama sepakat dan tidak ada pertentangan mengenai kebolehan hutang piutang, kesepakatan ini didasarkan pada tabiat manusia yang tidak bisa hidup tanpa pertolongan dan bantuan saudaranya . Oleh karena itu, hutang piutang sudah menjadi satu bagian dari kehidupan di dunia ini. Islam adalah agama yang sangat memperhatikan segenap kebutuhan umatnya.

Meskipun demikian, hutang piutang juga mengikuti hukum taklifi, yang terkadang dihukumi boleh, makruh, wajib, dan terkadang haram. Hukum dari pemberian hutang yang awalnya hanya dibolehkan yang bisa menjadi suatu hal yang diwajibkan jika diberikan kepada orang yang sangat membutuhkan.

Hukumnya haram jika meminjamkan uang untuk maksiat, mislanya untuk membeli narkoba atau yang lainnya. Dan hukumnya boleh jika untuk menambah modal usahanya karena berambisi mendapatkan keuntungan besar.

Haram bagi pemberi hutang mensyaratkan tambahan pada waktu akan dikembalikannya hutang. Utang-piutang ini dilaksanakan untuk membantu sesama manusia, menolong mereka menghadapi berbagai urusan, dan memudahkan saranasarana kehidupan. Akad dalam hutang piutang bukanlah salah satu sarana untuk memperoleh penghasilan dari memberikan hutang kepada orang lain. Oleh karena itu, diharamkan bagi pemberi hutang untuk mensyaratkan tambahan dari hutang yang dia berikan ketika mengembalikannya

Tetapi berbeda jika kelebihan itu adalah kehendak yang ikhlas dari orang yang berhutang sebagai balas jasa yang diterimanya, maka itu bukanlah riba dan dibolehkan serta menjadi kebaikan bagi si pemberi hutang. Karena ini terhitung sebagai al-husnul alqada'(membayar hutang dengan baik) (Antonio, 2001:132)

Berdasarkan beberapa penjelasan diatas yang menjadi dasarhukum utang-piutang melalui penjelasan Firman Allah SWT dan Hadits Nabi Muhammad SAW, penulis menguraikan bahwa utang -piutang merupakan salah satu bentuk akad yang disyari atkan Islam dengan melonggarkan kesempitan hidup sesama manusia, dan ini merupakan perbuatan yang terpuji dan mendapatkan pahala dari Allah SAW. Secara otomatis utang- 
piutang merupakan tindakan yang disunnahkan menurut hukum Islam, jika dilaPkukan sesuai dengan batasan-batasan yang diperbolehkan syara.

\section{Rukun dan Syarat Utang}

Berbicara mengenai utang-piutang atau ( $\operatorname{ardh})$, terdapat rukun dan syarat dalam melaksanakannya, tanpa kedua hal tersebut suatu akad dapat dikatakan tidak sah karna tidak terdapat rukun dan syaratnya, maka akad dan transaksi ini dapat dikatan sah jika memenuhi rukun dan syarat.

1. Shighah

Yang dimaksud shighah adalah ijab dan qabul. Tidak ada perbedaan dikalangan fuqaha "e bahwa ijab itu sah dengan lafal hutang dan dengan semua lafaz yang menunjukkan maknanya, seperti kata, "aku memberimu hutang” atau "aku menghutangimu”.

Demikian pula qabul sah dengan semua lafal yang menunjukkan kerelaan, seperti "aku berhutang" atau "aku menerima" atau "aku ridha" dan lain sebagainya.

\section{Aqidain}

Yang dimaksud dengan aqidain (dua pihak yang melakukan transaksi) adalah pemberi hutang dan penghutang, keduanya mempunyai beberapa syarat yang dijadikan sebagai acuan dalam praktek atau pelaksanaan utang piutang.

a. Syarat-syarat bagi pemberi hutang

Fuqaha $^{\text {ee }}$ sepakat bahwa syarat bagi pemberi hutang adalah termasuk ahli tabarru ${ }^{\text {ee }}$ (orang yang boleh memberikan derma), yakni merdeka, baligh, berakal shat, dan pandai (rasyid, dapat membedakan yang baik dan yang buruk). Mereka berargumentasi bahwa hutang piutang adalah transaksi irfaq (memberi manfaat).

Syafie ${ }^{\text {ee }}$ yyah berargumentasi bahwa al-qardh (hutang piutang) mengandung tabarru ${ }^{\text {ee }}$ (pemberian derma), bukan merupakan transaksi irfaq (memberi manfaat) dan tabarrue. Syafieiyah menyebutkan bahwa ahliyah (kecakapan, keahlian) memberi derma harus dengan kerelaan, bukan dengan paksaan. Tidak sah berhutang kepada orang yang dipaksa tanpa 
alasan yang benar, jika paksaan itu ada alasan yang haq seperti seseorang yang harus berutang dalam keadaan terpaksa, maka sah berhutang dengan memaksa.

Hanafiyah mengkritisi syarat ahliyah at-tabarrue (kecakapan memberi derma) bagi pemberi hutang bahwa tidak sah seorang ayah atau pemberi wasiat menghutangkan harta anak kecil. Hanabilah mengkritisi syarat ahliyah at-tabarrue (kelayakan member derma) bagi pemberi hutang bahwa seorang wali anak yatim tidak boleh menghutangkan harta anak yatim itu dan nazhir (pengelola) wakaf tidak boleh menghutangkan harta wakaf.

Syafieiyah merincikan permasalahan tersebut. Mereka berpendapat bahwa seorang wali tidak boleh menghutangkan harta orang yang dibawah perwaliannya kecuali dalam keadaan darurat jika tidak ada hakim. Adapun bagi hakim boleh menghutangkannya meskipun bukan dalam kondisi darurat.

b. Syarat bagi penghutang

1) Syafie iyah mensyaratkan penghutang termasuk kategori orang yang mempunyai ahliyah al-mueamalah (kelayakan melakukan transaksi) bukan ahliyah at-tabarru ${ }^{\text {ee }}$ (kelayakan member derma). Adapun kalangan ahnaf mensyaratkan penghutangkan mempunyai ahliyah at-tasharrufat (kelayakan memberikan harta) secara lisan, yakni merdeka, baligh, dan berakal sehat.

2) Hanabilah mensyaratkan penghutang mampu menanggung karena hutang tidak ada kecuali dalam tanggungan. Misalnya, tidak sah member hutang kepada masjid, sekolah, atau ribath (berjaga diperbatasan dengan musuh) karena semua ini tidak mempunyai potensi menanggung.

3. Harta yang dihutangkan

Rukun yang ketiga ini mempunyai beberapa syarat berikut.

a. Harta yang dihutangkan berupa harta yang ada padanannya, maksudnya harta yang satu sama lain dalam jenis yang sama tidak banyak berbeda yang megakibatkan perbedaan nilai, seperti uang, barang-barang yang dapat di takar, ditimbang, ditahan, dan dihitung. 
Tidak boleh menghutangkan harta yang nilainya satu sama lain dalam satu jenis berbeda beda. Yang perbedaan itu mempengaruhi harga, seperti hewan, pekarangan dan lain sebagainya. Hal ini karena tidak ada cara untuk mengembalikan barang dan tidak ada cara mengembalikan harga sehingga dapat menyebabkan perselisihan karena perbedaan harga dan taksiran nilainya. Demikian ini pendapat kalangan hanafiyah.

Malikiyyah dan Syafieciyyah, menurut pendapat yang paling benar di kalangan mereka, menyatakan bahwa boleh menghutangkan harta yang ada padanya. Bahkan, semua barang yang boleh ditransaksikan dengan cara salam, baik berupa hewan maupunlainnya, yakni semua yang boleh diperjual belikan dan dapat dijelaskan sifat-sifatnya meskipun harta itu berupa sesuatu yang berubah-ubah harganya. Mereka berargumentasi bahwa nabi Muhammad SAW pernah berhutang unta muda sehingga masalah ini dikiaskan dengannya.

Tidak boleh menghutangkan sesuatu yang tidak boleh diperjual belikan dengan cara salam, yakni sesuatu yang tidak dapat dijelaskan dengan sifat, seperti permata dan lain sebagainya. Hanya saja, Syafiei iyyah mengecualikan sesuatu yang tidak boleh dijual dengan salam, yakni hutang roti dengan timbangan karena adanya kebutuhan dan toleransi. Hanabilah berpendapat bahwa bolehmenghutangkan semua benda yang boleh dijual, baik yang ada padanannya maupun yang berubah-ubah harganya, baik yang dapat djelaskan dengan sifat maupun tidak.

b. Harta yang dihutangkan disyaratkan berupa benda, tidak sah menghutangkan manfaat (jasa). Ini merupakan pendapat kalangan Mazhab Hanafiyyah dan Hanabilah. Berbeda dengan kalangan syafieciyyah dan malikiyyah, mereka tidak mensyarat kan harta yang dihutangkan berupa benda sehingga boleh saja menghutangkan manfaat (jasa) yang dapat dijelaskan dengan sifat. Hal ini karena bagi mereka semua yang boleh diperjualbelikan dengan cara salam boleh dihutangkan, sedangkan bagi mereka salam boleh pada manfaat (jasa). Seperti halnya benda padaa umumnya.

Pendapat yang dipilih oleh ibnu taimiyyah dan ahli ilmu lainnya adalah bolehnya menghutangkan manfaat (jasa).

c. Harta yang dihutangkan diketahui. Syarat ini tidak dipertentangkan oleh fuqaha ${ }^{e e}$ karena dengan demikian penghutang dapat membayar hutangnya dengan harta yang sama. 
Syarat ketiga ini mencakup dua hal, yaitu:

1) Diketahui kadarnya

2) Diketahui sifatnya. Demikian ini agar mudah membayarnya. Jika hutang piutang tidak mempunyai syarat ketiga ini, maka tidak sah (Ath-Thayar:159-164).

Namun selain rukun dan syarat utang-piutang diatas, terjadi juga perselisihan oleh para ahli Fiqh. Menurut Hanafiah, rukun qard adalah ijab dan qabul. Sedangkan menurut jumhur ulama, rukun utang piutang adalah:

1. Aqid (orang yang berakad)

2. Dana atau objek pinjaman (qard)

3. Ijab qabul (sighat) (Zulkifli:27).

Demikian juga menurut Sulaiman Rasjid rukun utang piutang adalah:

1. Pihak yang berutang (muqtarid) dan yang memberi utang (muqrid)

2. Barang atau objek yang akan diutangkan.

3. Lafadh atau Ijab qabul (Rasjid: 307).

Dengan demikian, maka dalam transaksi utang piutang atau qard dianggap telah terjadi apabila sudah memenuhi rukun dan syarat dari pada utang-piutang itu sendiri. Adapun yang menjadi rukun dan syarat utang-piutang adalah:

1. Aqid (orang yang berakad), yakni muqrid dan muqtarid orang yang berhutang dan memberi utang mempunyai kesepakatan dalam melakukan akad. Artinya muqrid (pemberi utang) dan muqtarid (orangyang berhutang) adalah orang yang mempunyai kecakapan untuk melakukan perbuatan hukum, dengan syarat:
a. Baligh
b. Berakal
c. Dapat berlaku dewasa 


\section{d. Berkehendak sendiri tanpa paksaan}

e. Boleh untuk melakukan tabarru' (berderma).

Karena qard adalah bentuk akad tabarru' sehingga tidak boleh dilakukan oleh anak kecil, orang gila, orang yang dipaksa. Hal itu karenamereka semua bukanlah orang yang dibolehkan melakukan akad tabarru' (az-Zuhaili: 379).

Sementara dalam Fiqh sunnah disebutkan bahwa akad orang gila, orang mabuk, anak kecil yang belum mampu membedakan mana yang baik dan buruk, itu tidak sah. Namun anak kecil yang telah mampumemilih akadnya dinyatakan sah, hanya keabsahannya tergantung pada izin walinya.

Di samping itu orang yang melakukan utang-piutang hendaknya orang yang mempunyai kebebasan memilih, yakni bebas untuk melakukan perjanjian utang-piutang, terlepas dari paksaan dan tekanan. Sehingga dapat terpenuhi adanya prinsip suka rela, oleh karena itu tidak sah transaksi utang-piutang yang dilakukan karena adanya paksaan (Sabiq: 38).

2. Dana atau objek utang piutang (qard)

Menurut Hanafiyah harta yang dipinjamkan haruslah harta mithli, yaitu harta yang memiliki persamaan dan kesetaraan di pasar. Sedangkan jumhur ulama memperbolehkan dengan harta apa saja yang bisa dijadikan tanggungan, seperti uang dan biji-bijian. Dan harta qimi seperti hewan, barang tak bergerak dan lainnya (Syafe'I, 2001:38).

Untuk itu objek utang piutang harus memenuhi syarat-syarat sebagai berikut:

a. Merupakan benda bernilai dan mimiliki persamaan dan kesetaraan dipasar.

b. Jelas ukurannya, baik dalam takaran, timbangan, bilangan, maupun ukuran panjang supaya mudah dikembalikan (az-Zuhaili:378-379).

c. Harta yang berbentuk uang harus jelas nilainya.

d. Milik sempurna dari pemberi utang(muqrid). 
e. Dapat diserahkan pada waktu akad serta harus dibayar dalam jumlah dan nilai yang sama dengan yang diterima dari pemiliknya (muqrid) (Muqrid:224).

3. Ijab qabul (sighat)

Akad qard dilakukan dengan sighat Ijab qabul atau bentuk lain yang bisa mengantikannya, seperti cara mu,,atah (melakukan akad tanpa ijab qabul) dalam pandangan jumhur. Meskipun menurut Syafieeiyah tidaklah cukup sebagaimana dalam akad -akad lain. Sighat ijab adalah pernyataan pihak yang memberikan utang, sedangkan sighat qabul adalah pernyataan muqtarid menerima ijab yang diucapkan oleh muqrid.

Sighat ijab bisa dengan menggunakan lafal qard (utang atau pinjam) dan salaf (utang), atau dengan lafal yang mengandung arti kepemilikan. Contohnya: "Saya milikkan kepadamu barang ini, denganketentuan engkau harus mengembalikan kepada saya penggantinya". Penggunaan kata milik disini bukan diberikan secara cuma-cuma, melainkan pemberian utang yang harus dibayar (az-Zuhaili:375).

\section{Hadis Nabi yang Berkaitan dengan Utang}

Perbuatan yang cukup sulit adalah ketika seseorang harus membayar utangnya, sering terjadi perselisihan diantara pihak dikarenakan salah satu pihak ingkar terhadap kesepakatan awal. Padahal membayar utang merupakan kewajiban yang harus dilaksanakan, hal ini tergambar pada hadist Nabi sebagai berikut:

"Telah menceritakan kepada kami 'Abdullah bin Muhammad berkata, telah menceritakan kepada kami 'Utsman bin 'Umar berkata, telah mengabarkan kepada kami Yunus dari Az Zuhri dari 'Abdullah bin Ka'b bin Malik dari Ka'b, bahwa ia pernah menagih hutang kepada Ibnu Abu Hadrad di dalam Masjid hingga suara keduanya meninggi yang akhirnya didengar oleh Rasulullah saw., yang berada di rumah. Beliau kemudian keluar menemui keduanya sambil menyingkap kain gorden kamarnya, beliau bersabda: Wahai Ka'b!" Ka'b bin Malik menjawab: Wahai Rasulullah, aku penuhi panggilanmu. Beliau bersabda: Bebaskanlah hutangmu ini. Beliau lalu memberi isyarat untuk membebaskan setengahnya. Ka'b bin Malik menjawab, sudah aku lakukan wahai 
Rasulullah." Beliau lalu bersabda (kepada Ibnu Abu Hadrad): Sekarang bayarlah" (HR. Muslim) (Imam Abu Husaini Muslim bin Al-Hajaz An-Naisaburi, Juz. 5: 30).

Hadis di atas menjelaskan bahwa suatu kebajikan apabila melunasi utang dengan sesegera mungkin tanpa harus di tagih-tagih oleh pemberi utang, namun tidak jarang kita jumpai di tengah masyarakat kita, banyak orang yang berutang, mereka enggan membayarkan kewajibannya ketika waktu pelunasan sudah jatuh tempo. Kewajiban segera membayar utang, termasuk utang seseorang yang meninggal dunia, hal ini dilakukan belumlah boleh dikuburkan sebelum selesai utang atau adanya pengakuan utang dari keluarga yang ditinggalkan, hal ini sesuai dengan hadis Rasulullah:

"Telah menceritakan kepada kami Musaddad telah mengabarkan kepada kami Bisyir bin al Mufadhdhal telah menceritakan kepada kami Husain al Mu'alim dari 'Atha' dari Jabir ra., berkata; Ketika terjadi perang Uhud, pada suatu malamnya bapakku memanggilku seraya berkata,: "Tidaklah aku melihat diriku (menduga) melainkan aku akan menjadi orang yang pertama-tama gugur diantara para sahabat Nabi saw., (dalam peperangan ini) dan aku tidak meninggalkan sesuatu yang berharga bagimu sepeninggalku melainkan diri Rasulullah saw., dan aku mempunyai hutang, maka lunasilah dan berilah nasehat yang baik kepada saudara-saudaramu yang perempuan". Pada pagi harinya kami dapati bapakku adalah orang yang pertama gugur dan dikuburkan bersama dengan yang lain dalam satu kubur. Setelah itu perasaanku tidak enak dengan membiarkan dia bersama yang lain, maka kemudian aku keluar setelah enam bulan lamanya dari hari pemakamannya dan aku dapati jenazah bapakku masih utuh sebagaimana hari dia dikebumikan dan tidak ada yang berubah padanya kecuali sedikit pada ujung bawah telinganya" (HR. Bukhari) (Abu Abdullah Muhammad bin Ismail al-Bukhary al-Jami“e al-Shahih, 414-415).

\section{Kesimpulan}

Islam mengenal modal sebagai suatu komponen utama dalam usaha, dan hak atas modal diakui dalam Islam sebagai hak individu atau golongan yang berbeda dengan hak atas modal menurut pandangan kapitalis.Pada kapitalis modal merupakan hak mutlak individu.

Semua aktifitas yang dilakukan oleh seorang muslim, hendaklah dilakukan secara sungguh-sungguh, agar apa yang dilakukannya akan mendapatkan nilai yang sempurna di 
dunia dan akherat. Dalam kegiatan muamalah yang dilakukan, hendaklah memperhatikan utang, utang adalah sebagai metode terakhir dalam meraih nilai dan bila mengandung nilai keterpaksaan dan idealnya berusaha agar jangan terlibat di dalamnya. Utang dayn tidak ada tambahan dan murni dikembalikan sebagaimana pada saat dipinjam, sedangkan utang qardh adalah utang piutang yang dilakukan pada perbankan, hal ini merupakan pembiyaan yang memiliki unsur bisnis.

Bagi seorang muslim yang terpaksa berutang karena suatu hal, maka hendaklah memperhatikan utang, jangan utang dijadikan faktor utama yang bisa menyengsarakan kita di dunia dan akherat, karena tidak jarang kita jumpai karena persoalan utang, kehidupan seseorang menjadi tidak bahagia dan bahkan menjadi permasalahan yang tidak selesaiselasai. Padahal utang itu akan dipertanggungjawabkan dari diri kita sejak hidup hingga kita mati.

\section{DAFTAR ISI}

Al-Husain, Abu al-Kasim bin Muhammad. al-Mufradad fi Gharibil quran. t.tp: Nazar Mustafa al-Baz, tt. Al-Mu'jam al-wasid. Mesir: Maktabah Suru' Dawliyah, 2004.

Antonio, Muhammad Syafii. Bank Syariah Dari Teori Ke Praktik. Jakarta: Gema Insani Press, 2004.

Arifin, Zainul. Dasar-Dasar Manajemen Bank Syariah Edisi Revisi. Cet 4. Jakarta: Pustaka Alvabet, 2006.

Ath-Thayar, Muhammad bin Abdullah. Fiqh Muamalah.

Ath-Thayyar, Abdullah bin Muhammad. Ensiklopedia Fiqh Muamalah Dalam Pandangan 4 mazhab. Yogyakarta: Maktabah al-Hanif, 2009.

az-Zuhaili, Wahbah. Fiqh Islam. Jilid 5. Abdul Hayyie al-Kattani.

Huda, Nurul. Dalam Keuangan Publik Islami;Pendekatan Teoritis dan Sejarah. Jakarta: Kencana, 2012.

Ilyas, Rahmat. "Manajemen Permodalan Bank Syariah." Jurnal Bisnis dan Manajemen Islam 5, no. 2 (Desember 2017): 323-338. 
Ramdansyah, Abdul Aziz. "Esensi Utang Dalam Konsep Ekonomi Islam." Jurnal Bisnis dan Manajemen 4, no. 1 (Juni 2016): 125-135.

Rasjid, Sulaiman. Fiqh Islam.

Sabiq, Sayyid. Fiqh Sunnah. Jilid 4. Jakarta: Pena Pundi Aksara, 2011.

-. Fiqh Sunnah. Jilid 5. Abu Syauqina.

Syafe ${ }^{e i,}$ Rachmat. Fiqh Muamalah. Bandung: CV. Pustaka Setia, 2011.

Syarifuddin, Amir. Garis-Garis Besar Fiqh.

Zulkifli, Sunarto. Panduan Praktis Transaksi Pebankan Syariah. 